\title{
TERMS DENOTING PARTS OF A TREE - A CONTRASTIVE APPROACH
}

\author{
Alexandra STAN* \\ Transilvania University of Brașov, Romania
}

\begin{abstract}
The frequent misuse of specialized terms by forestry students, due to the wrong assumption that they are synonymous, requires an endeavor to detect and correct inaccuracies in monolingual and bilingual lexicography for a more efficient process of learning and/or teaching L2. In this spirit, the aims of this article are to identify the denominations of the parts of a tree in Romanian and English, and to verify their equivalence in both languages. The method used to describe and examine this sector of the lexicon is the semic analysis, commonly applied in lexical field theory. The first section of the article presents a brief theoretical overview of the lexical field theory and the methodological framework. The discussion continues with the semic analysis of a number of lexemes denoting parts of a tree in Romanian, which is based on the lexicographic and terminological definitions, and ends with several observations regarding the distinction between these two types of definitions (section two). Section three is dedicated to the semantic analysis of the English equivalents of the Romanian lexemes, while the last section reveals important concluding remarks related to the similarities and differences between the two language systems. The desired final product of this research resides in its didactic applicability, more specifically in efficient methods of L1 and L2 lexical acquisition.
\end{abstract}

Keywords: lexical field theory; semic analysis; lexicographic definition; terminological definition; lexical acquisition

\section{INTRODUCTION}

Terminological definitions, also known as the specialists' definitions, are usually monosemantic, while lexicographic definitions are descriptive and polysemantic. When teaching English as a second language, this distinction is not so easily

\footnotetext{
*stan.alexas@gmail.com
} 
made. For instance, the word "tree" can be translated into Romanian as "arbore", "copac", or "pom", but only the first translation is considered a specialized term.

First and second year forestry undergraduate students have trouble distinguishing or identifying the correct English equivalents of certain Romanian specialized terms. These errors stem from their confusion of meanings in the source language (e.g. "cracă" vs. "ramură", "coajă" vs. "scoarţă", "trunchi” vs. "tulpină" vs. "fus"). What follows is their inability to accurately translate these terms into English ("branch” vs. "bough”, "bark” vs. "cortex", "trunk" vs. "stem" vs. "bole"). Although the students' gradual acquisition of content schemata neutralizes these gaps in knowledge, they would benefit from an earlier clarification or correction of such problems, which would lead to more effective and accurate communication in academic and/or professional settings.

Having familiarized themselves with the meanings in the source language, lexical acquition in L2 would proceed more efficiently if the lexemes were taught using a parallel representation in both languages. Thus, the differences in lexicalization would be rendered and observed more clearly, enabling the learning or teaching of L2 without too much reliance on bilingual dictionaries. As a small step in this direction, the present article aims to identify terms denoting parts of a tree in Romanian and English, to verify the equivalences between the Romanian terms and the English terms, and to facilitate L1 and L2 lexical acquisition. The semic analysis commonly used in lexical field theory is the method used to accomplish these aims.

This contrastive analysis consists of several steps. The first one is to reorganize the information contained in the lexicographic and terminological definitions, so that the similarities and differences between the lexemes can be identified. These similarities and differences are then abstracted in the form of semes and semic definitions. The final step is the contrastive analysis of the lexicographic and terminological definitions, which provides interesting observations and distinctions between the two language systems.

\section{THEORETICAL BACKGROUND}

A methodology used in structuralist semantics, lexical field theory emerged and developed between the 1930s and the 1960s predominantly in the work of German and French scholars (most notably Jost Trier), while componential analysis, the method used to describe the internal relations within a field, was pioneered by Eugenio Coşeriu, Bernard Pottier, and Algirdas Greimas in the 1960s, from the European tradition of lexical field research (Geeraerts 52-53).

Although the labels lexical field and semantic field have been used in free variation by some linguists, others have made clear-cut distinctions between them (cf. Lehrer, qtd. in Lipka 93, Lyons 268). This paper will adopt the former label, with Coşeriu's (31) definition of lexical field as "a paradigm consisting of 
content-laden lexical units (lexemes) which share a common area of meaning and are in direct contrast with one another" [my translation $]^{11}$. Various field typologies exist in the literature, but the one relevant for this analysis belongs to Bidu-Vrănceanu and Forăscu (165), who have categorized fields according to the number of lexical-semantic paradigms present in a field. Fields which consist of one paradigm are classified as monoparadigmatic and fields which contain more than one paradigm are polyparadigmatic. Lexical fields described so far by Geckeler, Baldinger, de Chanay, or Wotjack (cf. Bidu-Vrănceanu, Câmpuri lexicale din limba română 72) have included terms denoting colours, animals, furniture etc. in Romance languages. Romanian forest terminology has been analyzed by Botnaru (2008) and Biriş (2011), who focused on the etymological stratification and semantic organization of forest-related words and tree-related words (i.e. words denoting tree species), and, respectively, the semantic description of forest-related denominations. In what follows, an overview of the most important concepts used in the semic analysis is provided for a better understanding of this method.

The componential/semic analysis employs such concepts as semes, also known in the literature as semantic features, semantic components, semantic markers or semantic primes, which are defined as "smaller, more elementary, invariant units of meaning" (Cruse 98). Semes are difficult to represent in metalanguage, resulting after the information in the lexicographic and/or terminological definitions is abstracted. This is a process which requires that the common or recurring items of information in the definition be identified, generalized, and rendered by means of univocal, unanimously understood concepts.

A collection of semes which describe a lexical meaning is defined as a sememe. There are numerous classifications of semes, depending on their configuration in a sememe, but the present analysis makes use of three categories: common, variable, and residual. Common semes are central in a lexical field, while variable semes have a defining, differentiating role (BiduVrănceanu, Câmpuri lexicale din limba română 24). Common and variable semes occur in oppositive pairs, while residual semes are represented by unopposable semantic units, because they include encyclopedic information which normally would be eliminated for a clearer, more rigorous identification of meaning.

The combination of a sememe and a signifier is a lexeme, and a number of lexemes form a word. Lexemes are monosemantic, while words can be either mono- or polysemantic.

\footnotetext{
11 “paradigme constitué par des unités lexicales de contenu (lexèmes) se partageant une zone de signification continue commune et se trouvant en opposition immédiate les unes avec les autres.”
} 


\section{ROMANIAN LEXEMES DENOTING PARTS OF A TREE}

This paper is intended as a starting point for more extensive research, so the wordlist is short, consisting of lexemes ${ }^{12}$ from the category of nouns used in standard language (see Table 1 below), which were extracted from general monolingual dictionaries (see Works cited). The common semes for this lexical field, represented between forward slashes and included in all the sememes, are /part of tree/ and /location/. Taking into account that some of the words on the list are polysemantic, the present examination is limited to the denotative, contextually independent meanings ${ }^{13}$ relevant for this analysis.

The identification of the recurring elements, i.e. the common semes, entails three steps (Bidu-Vrănceanu, Câmpuri lexicale din limba română 278): (i) a process of careful reading of the definitions, followed by the reorganization of the items of information in the definitions to facilitate comparison and contrast, (ii) the rigorous formulation of the genus proximum excluding the differentia specifica, and (iii) the elimination of redundant information and/or encyclopedic data.

The analysis of the Romanian lexemes starts with the lexicographic and semic definitions of the denominations for the concept of tree, i.e. ARBORE / COPAC ("tree"). According to Riemer (140), the lexical relation between such lexemes as ARBORE and COPAC and the terms denoting a tree's parts/organs is meronymy (Greek meros = "part"), because it conveys the relation of part to whole. Thus, ARBORE and COPAC are holonyms of its parts, while these in turn are meronyms of ARBORE and COPAC. The two Romanian denominations for the concept of tree are defined below:

a) ARBORE ("tree") = "generic name given to any plant which has a tall, strong, woody trunk with many branches and leaves which form a crown" ${ }^{14}$

b) COPAC ("tree" ${ }^{15}$ ) = "perennial plant with a tall, woody trunk, whose branches grow a certain distance over the soil, forming a crown; fruittree" ${ }^{\prime 16}$.

\footnotetext{
${ }^{12}$ Represented in capital letters.

${ }^{13}$ In this article, the acceptation of meaning is a "contextually independent sum of semes” (Bidu-Vrănceanu et al., Dicţionar de Ştiinţe ale Limbii).

14 “nume generic pentru orice plantă cu trunchi înalt şi puternic, lemnos şi cu mai multe ramuri cu frunze care formează o coroană; copac"

15 The specialized multilingual dictionary (see Works cited) used for the translation of the Romanian lexemes does not contain a separate entry for this denomination, which is why its translation was based on its synonymy with ARBORE.

16 “plantă vivace cu trunchiul lemnos şi înalt, ale cărei crengi se ramifică la o distanţă oarecare de sol, formând o coroană; arbore, pom”
} 
These lexicographic definitions include the lexeme COPAC as a synonym for ARBORE, and the lexemes ARBORE and POM ("fruit-tree") as synonyms for COPAC. The only English equivalent for ARBORE and COPAC is TREE, which is why it was not repeated in the English translation ${ }^{17}$. The recurring elements in the definitions of the synonymous pair ARBORE=COPAC are /woody plant/, /tall trunk/, /crown/. These common semes are necessary for a better organization of the lexemes in this lexical field, which are grouped into two paradigms, according to the general area on a tree where the part/organ is found:

a) MAIN BODY: TRUNCHI ("trunk, stem"), TULPINĂ (“stem"), FUS ("stem, bole"), SCOARŢĂ ("bark, rind, cortex"), COAJĂ ("bark, rind, cortex");

b) CROWN: RAMURĂ ("branch, bough”), CRACĂ ("branch, bough”), CREANGĂ ("branch, bough”), LĂSTAR ("shoot, sprout”), LUJER (“shoot, sprout”), MLADĂ (“shoot, sprout”).

Table 1 The Romanian lexemes and their lexicographic definitions

\begin{tabular}{|c|c|c|}
\hline PARADIGM & $\begin{array}{l}\text { ROMANIAN } \\
\text { LEXEME }\end{array}$ & LEXICOGRAPHIC DEFINITION \\
\hline \multirow{4}{*}{$\begin{array}{l}\text { MAIN } \\
\text { BODY }\end{array}$} & $\begin{array}{l}\text { TRUNCHI } \\
\text { (“trunk, stem”) }\end{array}$ & $\begin{array}{l}\text { "the thickest part of a tree, between the } \\
\text { root and the place where the main } \\
\text { branches develop; stem""18 }\end{array}$ \\
\hline & $\begin{array}{l}\text { TULPINĂ } \\
\text { ("stem") }\end{array}$ & $\begin{array}{l}\text { "part of a tree between the root and the } \\
\text { crown, which supports the branches, } \\
\text { leaves, flowers, and fruit, and transports } \\
\text { sap to various parts of the plant; } \\
\text { trunk/stem"19 }\end{array}$ \\
\hline & $\begin{array}{l}\text { FUS } \\
\text { ("stem, bole") }\end{array}$ & $\begin{array}{l}\text { "the trunk/stem of a tree from base to } \\
\text { top, lacking branches/boughs" } 20\end{array}$ \\
\hline & $\begin{array}{l}\text { SCOARŢ Ă } \\
\text { ("bark, rind, cortex”) }\end{array}$ & $\begin{array}{l}\text { "(thick, hard) protective tissue which } \\
\text { covers the stem and root of plants; } \\
\text { bark/rind/cortex"21 }\end{array}$ \\
\hline
\end{tabular}

\footnotetext{
${ }^{17}$ All the translations of the Romanian lexicographic and terminological definitions are mine.

18 "partea cea mai groasă a unui copac, cuprinsă între rădăcină şi locul de unde pornesc ramurile principale; tulpină"

19 "parte a unui arbore cuprinsă între rădăcină şi coroană, care susţine ramurile, frunzele, florile şi fructele şi prin care trece seva la diverse părţi ale plantei; trunchi"

20 "trunchiul unui copac de la bază până la vârf, fără crengi"

21 "ţesut protector (gros şi tare) care acoperă tulpina şi rădăcina plantelor; coajăa"
} 


\begin{tabular}{|c|c|c|}
\hline & $\begin{array}{l}\text { COAJÄ } \\
\text { ("bark, rind, cortex") }\end{array}$ & $\begin{array}{l}\text { "external protective tissue, made of big } \\
\text { cells, found on roots, stems, and } \\
\text { branches of } \\
\text { bark/rind/cortex"22 }\end{array}$ \\
\hline \multirow{6}{*}{ CROWN } & $\begin{array}{l}\text { RAMURĂ } \\
\text { ("branch, bough") }\end{array}$ & $\begin{array}{l}\text { "each of the ramifications of a plant } \\
\text { stem" } 23\end{array}$ \\
\hline & $\begin{array}{l}\text { CRACĂ } \\
\text { ("branch, bough") }\end{array}$ & "(thicker) branch/bough of a tree" \\
\hline & $\begin{array}{l}\text { CREANGÄ } \\
\text { ("branch, bough" } 25 \text { ) }\end{array}$ & "branch/bough of a tree"26 \\
\hline & $\begin{array}{l}\text { LĂSTAR } \\
\text { ("shoot, sprout") }\end{array}$ & $\begin{array}{l}\text { "young branch/bough which develops } \\
\text { from the root or stem of a woody } \\
\text { plant"27 }\end{array}$ \\
\hline & $\begin{array}{l}\text { LUJER } \\
\text { ("shoot, sprout") }\end{array}$ & $\begin{array}{l}\text { "young branch/bough (1-2 years old) of } \\
\text { woody plants" } 28\end{array}$ \\
\hline & $\begin{array}{l}\text { MLADÄ } \\
\text { ("shoot, sprout") }\end{array}$ & $\begin{array}{l}\text { "young, thin, flexible branch/bough of a } \\
\text { woody plant; shoot/sprout" } 29\end{array}$ \\
\hline
\end{tabular}

The common semes of the paradigm MAIN BODY are /part of tree/ abstracted from such items of information as "part of a tree" and "tissue", /location/ - abstracted from information about the area on the tree where the part / organ is found, and /function/ - abstracted from the elements "supports the branches", "transports sap", "protective”, and "covers the stem".

The variable semes in this paradigm highlight the relevant similarities and differences in meaning for each lexeme. Thus, the semes /location/ and /function/ can each have two values: /between root and crown/ vs. /from base to top/, and, respectively, /supports the crown and transports sap/ vs. /covers and protects the main body/. Table 2.1 below illustrates the lexemes grouped according to their common and variable semes.

\footnotetext{
22 “ţesut protector extern, format din celule mari, al rădăcinilor, tulpinilor şi ramurilor unor plante (lemnoase); scoarţă"

23 "fiecare dintre ramificaţiile unei tulpini de plantă"

24 "ramură (mai groasă) a unui copac; creangă"

25 The specialized multilingual dictionary (see Works cited) used for the translation of the Romanian lexemes does not contain a separate entry for this denomination, which is why its translation was based on its synonymy with CRACĂ.

26 "ramură a unui copac; cracă"

27 “ramură tânără care se dezvoltă din rădăcina sau tulpina unei plante lemnoase"

28 "ramură tânără (de 1-2 ani) la plantele lemnoase"

29 “ramură tânără, subţire şi flexibilă a unei plante lemnoase; lăstar, vlăstar"
} 
Table 2.1 Common and variable semes of the Romanian lexemes in the paradigm MAIN BODY

\begin{tabular}{|l|l|l|l|}
\hline \multicolumn{2}{|l|}{$\begin{array}{l}\text { Common semes: /part of tree/ } \\
\text { /location/ /function/ }\end{array}$} & $\begin{array}{l}\text { /function/ } \\
\text { /supports the crown } \\
\text { and transports sap/ }\end{array}$ & $\begin{array}{l}\text { /covers and } \\
\text { protects the main } \\
\text { body/ }\end{array}$ \\
\hline \multirow{3}{*}{$/$ location// } & $\begin{array}{l}\text { between root and } \\
\text { crown/ }\end{array}$ & $\begin{array}{l}\text { TRUNCHI } \\
\text { TULPINĂ }\end{array}$ & \\
\cline { 2 - 4 } & /from base to top/ & FUS & $\begin{array}{l}\text { SCOARŢ̆ } \\
\text { COAJĂ }\end{array}$ \\
\hline
\end{tabular}

The following opposition series are identified, in terms of:

a) /location/: /between root and crown/ vs. /from base to top/: TRUNCHI, TULPINĂ vs. FUS, SCOARŢĂ, COAJĂ;

b) /function/: /supports the crown and transports sap/vs. /covers and

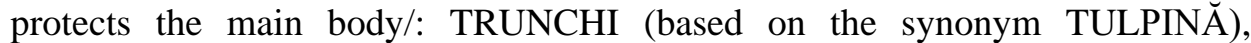
TULPINĂ, FUS (based on the genus proximum TRUNCHI) vs. SCOARŢĂ, COAJĂ.

The lexemes in the paradigm CROWN include the common semes /part of tree/ - abstracted from the item of information "ramification", /location (stem)/, /shape/ - abstracted from the elements "thicker" and "thin", with the values /thick/ vs. /thin/, and /age/ - abstracted from the item of information "young", with the values /mature/ ${ }^{30}$ vs. /young/. In table 2.2 below, the lexemes in the paradigm CROWN are grouped according to their common and variable semes.

Table 2.2 Common and variable semes of the Romanian lexemes in the paradigm CROWN

\begin{tabular}{|c|c|c|c|}
\hline \multirow{2}{*}{\multicolumn{2}{|c|}{$\begin{array}{l}\text { Common semes: /part of tree/ } \\
\text { /location (stem)//shape//age/ }\end{array}$}} & \multicolumn{2}{|l|}{ /age/ } \\
\hline & & /mature/ & /young/ \\
\hline \multirow[t]{2}{*}{ /shape/ } & /thick/ & $\begin{array}{l}\text { RAMURĂ } \\
\text { CRAC } \breve{~} \\
\text { CREANGA }\end{array}$ & \\
\hline & /thin/ & & $\begin{array}{l}\text { LĂSTAR } \\
\text { LUJER } \\
\text { MLADĂ }\end{array}$ \\
\hline
\end{tabular}
30 Applied to the cases when the lexicographic definition does not explicitly state
"young". 
The opposition series in this paradigm are identified, in terms of:

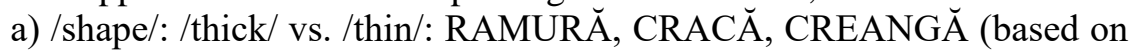
the synonym CRACĂ) vs. LĂSTAR (based on the synonymy with MLADĂ), LUJER, MLADĂ (based on the synonym LĂSTAR);

b) /age/: /mature/vs. /young/: RAMURĂ, CRACĂ, CREANGĂ vs. LĂSTAR, LUJER, MLADĂ.

An interesting outcome of the semic definitions for the two paradigms above is that the full synonymy is confirmed in the case of the lexemes TRUNCHI=TULPINĂ, RAMUR $\breve{A}=$ CRAC $\breve{A}=C R E A N G \breve{A}$, and LĂSTAR=LUJER=MLADĂ.

The next subsection discusses the differences between lexicographic and terminological definitions. One of the main differences between these types of definitions is that lexicographic definitions are descriptive and defined, among others, by means of synonyms (cf. Svensén, Ilson, Geeraerts, qtd. in Burada, Sinu 130-32), while terminological definitions must be simple, univocal, nondependent on contexts, and characterized by the rigorous reference to a certain domain, e.g. silviculture (Bidu-Vrănceanu, Lexicul specializat în mişcare 32). Lexicographic definitions consist of definitions of headwords, while terminological definitions describe the meaning of specialized items which make up the lexicon of specific professional communities, namely terms. When the use of standard language overlaps with the use of terminology, the latter migrates toward the former, creating the process known as determinologization (cf. Bidu-Vrănceanu, Lexicul specializat în mişcare 161; Meyer and Mackintosh, qtd. in Bowker 156), whereby specialized terms are assimilated into standard language, due to the gradual "dilution" [my translation] of their scientific meaning.

The terminological definitions of the Romanian lexemes, extracted from the specialized glossary Terminologia forestieră română (Popovici 1978), are listed in Table 3 below. Admittedly, Popovici's glossary of terms is rather old, but it is still in use considering the lack of more recent comprehensive and rigorous forestry dictionaries or glossaries. The holonym of this field is represented by the same two denominations for the concept of tree, with their terminological definitions:

a) ARBORE (“tree”) = "(dendrology, silviculture) woody plant with a height of at least $7 \mathrm{~m}$, having a distinguishable trunk and crown"31;

b) COPAC ("tree”32) = "(dendrology, silviculture) tree" ${ }^{33}$.

\footnotetext{
31 “(dendrologie, silvicultură): sin. copac; plantă lemnoasă având înălţimea de cel puţin 7 m cu un trunchi şi o coroană distinctă”

${ }^{32}$ See footnote 5 .

33 arbore
} 
The terminological definition of ARBORE provides the synonym COPAC, and conversely, the definition of COPAC includes the lexeme ARBORE as a synonym. The common semes in the definitions of these two synonyms are /woody plant/, /trunk/, and /crown/. Due to the fact that both lexemes were included in this glossary, they were considered specialized terms. However, taking into account the publication date of the glossary and the theoretical principles of a variety of academics nowadays, who are instructing their students not to use the lexeme COPAC in academic or professional settings, it is acceptable to assume that it is no longer included under the umbrella of specialized terms.

Table 3 The Romanian lexemes and their terminological definitions

\begin{tabular}{|c|c|c|}
\hline PARADIGM & $\begin{array}{l}\text { ROMANIAN } \\
\text { LEXEME }\end{array}$ & TERMINOLOGICAL DEFINITION \\
\hline \multirow{5}{*}{$\begin{array}{l}\text { MAIN } \\
\text { BODY }\end{array}$} & $\begin{array}{l}\text { TRUNCHI } \\
\text { (“trunk, stem”) }\end{array}$ & $\begin{array}{l}\text { "(dendrometry) part of the stem of a tree } \\
\text { between the superior section of the stump } \\
\text { and the place where the crown starts } \\
\text { developing" } 34\end{array}$ \\
\hline & $\begin{array}{l}\text { TULPINĂ } \\
\text { ("stem") }\end{array}$ & $\begin{array}{l}\text { "(dendrometry) distinguishable part of a } \\
\text { tree situated above the root collar, which } \\
\text { carries branches/boughs, buds, leaves, } \\
\text { flowers, and fruit" } 35\end{array}$ \\
\hline & $\begin{array}{l}\text { FUS } \\
\text { ("stem, bole") }\end{array}$ & $\begin{array}{l}\text { "(dendrometry) section from the stem of a } \\
\text { tree, between the stump and the terminal } \\
\text { bud" } 36\end{array}$ \\
\hline & $\begin{array}{l}\text { SCOARŢĂ } \\
\text { ("bark, rind, } \\
\text { cortex") }\end{array}$ & $\begin{array}{l}\text { "part of the root or stem structure, made of } \\
\text { parenchyma with intercellular spaces"37 }\end{array}$ \\
\hline & $\begin{array}{l}\text { COAJĂ } \\
\text { ("bark, } \\
\text { cortex") }\end{array}$ & $\begin{array}{l}\text { "specific external tissue of the trunk/stem, } \\
\text { which covers the wood" } 38\end{array}$ \\
\hline
\end{tabular}

\footnotetext{
34 “(dendrometrie) parte din tulpina unui arbore de la secţiunea superioară a cioatei până la locul unde se dizolvă în coroană"

35 “(dendrometrie) parte diferenţiată a unui arbore situată deasupra coletului, care poartă crăci, muguri, frunze, flori şi fructe"

36 “(dendrometrie) porţiune din tulpina unui arbore, de la cioată până la mugurele terminal”

37 “parte din structura rădăcinii sau a tulpinii alcătuită dintr-un parenchim cu spaţii intercelulare"

38 "țesut exterior specific al trunchiului care înveleşte lemnul"
} 


\begin{tabular}{|c|c|c|}
\hline \multirow{6}{*}{ CROWN } & $\begin{array}{l}\text { RAMURĂ } \\
\text { ("branch, bough”) }\end{array}$ & "part derived from the stem or root"39 \\
\hline & $\begin{array}{l}\text { CRACÁ } \\
\text { ("branch, bough") }\end{array}$ & $\begin{array}{l}\text { "(dendrometry) woody part which } \\
\text { develops latterally and directly from the } \\
\text { stem of a tree and which develops } \\
\text { secondary branches/boughs, leaves, } \\
\text { flowers, and fruit" } 40\end{array}$ \\
\hline & $\begin{array}{l}\text { CREANGĂ } \\
(-)\end{array}$ & - \\
\hline & $\begin{array}{l}\text { LĂSTAR } \\
\text { (“shoot, sprout”) }\end{array}$ & $\begin{array}{l}\text { "(silviculture) shoot/sprout, section of the } \\
\text { stem which develops on the stump or stem } \\
\text { of a tree, from a dormant/resting or } \\
\text { adventitious bud" } 41\end{array}$ \\
\hline & $\begin{array}{l}\text { LUJER } \\
\text { ("shoot, sprout") }\end{array}$ & "shoot/sprout" 42 \\
\hline & $\begin{array}{l}\text { MLADÄ } \\
\text { ("shoot, sprout") }\end{array}$ & "shoot/sprout lacking ramifications" 43 \\
\hline
\end{tabular}

The terminological definitions in Table 3 are noticeably different from the lexicographic definitions in Table 1. Most of the terminological definitions include field labels: "silviculture”, "dendrometry".

In the paradigm MAIN BODY, in both types of definitions, the lexemes TRUNCHI, TULPINĂ, and FUS have the same values within the common seme /location/, albeit expressed differently, as underlined in the table below, while the common seme /function/ changes its status to a residual seme, because it only occurs in the case of the lexeme TULPINĂ, as illustrated in Italics below.

\begin{tabular}{|l|l|}
\hline Lexicographic definition & Terminological definition \\
\hline $\begin{array}{l}\text { TRUNCHI ("trunk, stem") } \\
\text { "the thickest part of a tree, between } \\
\text { the root and the place where the main } \\
\text { branches develop; stem" }\end{array}$ & $\begin{array}{l}\text { TRUNCHI ("trunk, stem”) } \\
\text { "(dendrometry) part of the stem of a } \\
\text { tree between the superior section of the } \\
\text { stump and the place where the crown } \\
\text { starts developing” }\end{array}$ \\
\hline $\begin{array}{l}\text { TULPINĂ ("stem") } \\
\text { "part of a tree between the root and }\end{array}$ & $\begin{array}{l}\text { TULPINĂ ("stem”) } \\
\text { "(dendrometry) distinguishable part of }\end{array}$ \\
\hline
\end{tabular}

39 "parte derivată din tulpină sau rădăcină"

40 "(dendrometrie) parte lemnoasă dezvoltată lateral şi direct din tulpina unui arbore şi pe care se dezvoltă ramuri secundare, frunze, flori şi fructe"

41 "(silvicultură): sin. lujer, porţiune de tulpină ce ia naştere pe cioata sau pe tulpina unui arbore, dintr-un mugure proventiv (dormind) sau adventiv (întâmplător)"

42 "sin. lăstar (v.)"

43 "lujer neramificat" 


\begin{tabular}{|l|l|}
\hline $\begin{array}{l}\text { the crown, which supports the } \\
\text { branches, leaves, flowers, and fruit, } \\
\text { and transports sap to various parts of } \\
\text { the plant; trunk/stem" }\end{array}$ & $\begin{array}{l}\text { which carries branches/boughs, buds, } \\
\text { leaves, flowers, and fruit" }\end{array}$ \\
\hline $\begin{array}{l}\text { FUS ("stem, bole") } \\
\text { "the trunk/stem of a tree from base to } \\
\text { top, lacking branches/boughs" }\end{array}$ & $\begin{array}{l}\text { FUS ("stem, bole") } \\
\text { "(dendrometry) section from the stem } \\
\text { of a tree, between the stump and the } \\
\text { terminal bud" }\end{array}$ \\
\hline
\end{tabular}

Regarding the distinction between COAJĂ vs. SCOARŢ $\breve{A}$ in the same paradigm, the full synonymy confirmed in the first part of the analysis is cancelled. The common seme /function/ changes into a residual seme in the case of the lexeme COAJĂ, and the distinction between this lexeme and SCOARŢA is visible due to the residual semes /covers the wood/ in the case of the former, and /composition/ in the case of the latter, as underlined on the right side of the table below. In other words, the part of the plant denoted by the lexeme COAJĂ covers the part of the plant denoted by the lexeme SCOARŢĂ.

\begin{tabular}{|c|c|}
\hline Lexicographic definition & Terminological definition \\
\hline $\begin{array}{l}\text { SCOARȚ A ("bark, rind, cortex") } \\
\text { "(thick, hard) protective tissue which } \\
\text { covers the stem and root of plants; } \\
\text { bark/rind/cortex" }\end{array}$ & $\begin{array}{l}\text { SCOARȚÄ ("bark, rind, cortex") } \\
\text { "part of the root or stem structure, } \\
\text { made of parenchyma with intercellular } \\
\text { spaces" }\end{array}$ \\
\hline $\begin{array}{l}\text { COAJĂ ("bark, rind, cortex") } \\
\text { "external protective tissue, made of } \\
\text { big cells, found on roots, stems, and } \\
\text { branches of (woody) plants; } \\
\text { bark/rind/cortex" }\end{array}$ & $\begin{array}{l}\text { COAJĂ ("bark, rind, cortex") } \\
\text { "specific external tissue of the } \\
\text { trunk/stem, which covers the wood" }\end{array}$ \\
\hline
\end{tabular}

In the paradigm CROWN, the semes /shape/ and /age/, underlined in the table below, disappear because the information regarding these aspects is absent in the terminological definitions. The distinction is made through residual semes, namely /origin (dormant / resting or adventitious bud)/, which was added to the semic definitions of the lexemes LĂSTAR, LUJER (based on the synonym LĂSTAR), and MLADĂ, and, respectively, /-components (ramifications)/, added to the semic definition of MLADĂ (illustrated in Italics below).

\begin{tabular}{|l|l|}
\hline Lexicographic definition & Terminological definition \\
\hline LĂSTAR ("shoot, sprout”) & LĂSTAR ("shoot, sprout”) \\
"young branch/bough which develops "(silviculture) shoot/sprout, section of \\
from the root or stem of a woody \\
$\begin{array}{l}\text { the stem which develops on the stump } \\
\text { plant" stem of a tree, from a a }\end{array}$
\end{tabular}




\begin{tabular}{|l|l|}
\hline & dormant/resting or adventitious bud" \\
\hline $\begin{array}{l}\text { MLADĂ ("shoot, sprout”) } \\
\text { "young, thin, flexible branch/bough of } \\
\text { a woody plant; shoot/sprout” }\end{array}$ & $\begin{array}{l}\text { MLADĂ ("shoot, sprout”) } \\
\text { "shoot/sprout lacking ramifications" }\end{array}$ \\
\hline
\end{tabular}

The lexeme CREANGĂ is missing from the list, which would indicate that it is not considered specialized. The semic analysis based on the lexicographic definitions yields a higher number of semes, thus attesting to the descriptive nature of this type of definition, as opposed to the terminological definitions, which lack such semes as /function/, /shape/, and /age/. Their absence is compensated by various residual semes. The full synonymy is confirmed in the case of the lexemes TRUNCHI=TULPINA RAMURA $=$ CRACĂ, and LĂSTAR=LUJER .

\section{ENGLISH LEXEMES DENOTING PARTS OF A TREE}

This section discusses the contrastive approach of the analysis, starting with the identification of the English equivalents of the Romanian lexemes, followed by the semic analysis, and ending with important distinctions between the lexicographic and terminological definitions.

The English translations were extracted from the multilingual specialized dictionary Dicţionar forestier poliglot român-englez-francez-german (Dincă et al. 2011). The holonym of the field, i.e. the lexeme TREE, has the following lexicographic definition: "a woody perennial plant having a single usually elongate main stem generally with few or no branches on its lower part". The common semes in this definition are /woody plant/, /perennial/, /tall stem/, /crown/. The common field semes are identical in both languages, i.e. /part of tree/ and /location/, as shown by the parallel analysis of the lexicographic definitions in Table 4 below.

Table 4 The English lexemes and their lexicographic definitions

\begin{tabular}{|l|l|l|}
\hline PARADIGM & $\begin{array}{l}\text { ENGLISH } \\
\text { LEXEME }\end{array}$ & LEXICOGRAPHIC DEFINITION \\
\hline \multirow{4}{*}{$\begin{array}{l}\text { MAIN } \\
\text { BODY }\end{array}$} & TRUNK & $\begin{array}{l}\text { "the main stem of a tree apart from limbs and } \\
\text { roots - called also bole" }\end{array}$ \\
\cline { 2 - 3 } & STEM & $\begin{array}{l}\text { "the main trunk of a plant; specifically a } \\
\text { primary plant axis that develops buds and } \\
\text { shoots instead of roots" }\end{array}$ \\
\cline { 2 - 3 } & BOLE & "trunk" \\
\cline { 2 - 3 } & BARK & "the tough exterior covering of a woody root \\
\hline
\end{tabular}




\begin{tabular}{|c|c|c|}
\hline & & $\begin{array}{l}\text { or stem; specifically the tissues outside the } \\
\text { cambium that include an inner layer } \\
\text { especially of secondary phloem and an outer } \\
\text { layer of periderm" }\end{array}$ \\
\hline & RIND & "the bark of a tree" \\
\hline & CORTEX & $\begin{array}{l}\text { "the typically parenchymatous layer of tissue } \\
\text { external to the vascular tissue and internal to } \\
\text { the corky or epidermal tissues of a green } \\
\text { plant; broadly all tissues external to the } \\
\text { xylem" }\end{array}$ \\
\hline & BRANCH & $\begin{array}{l}\text { "(botany) a natural subdivision of a plant } \\
\text { stem; especially a secondary shoot or stem } \\
\text { (such as a bough) arising from a main axis } \\
\text { (as of a tree)" }\end{array}$ \\
\hline CROWN & BOUGH & $\begin{array}{l}\text { "a branch of a tree; especially a main } \\
\text { branch" }\end{array}$ \\
\hline & SHOOT & $\begin{array}{l}\text { "a stem or branch with its leaves and } \\
\text { appendages especially when not yet mature" }\end{array}$ \\
\hline & SPROUT & $\begin{array}{l}\text { "shoot; especially a young shoot (as from a } \\
\text { seed or root)" }\end{array}$ \\
\hline
\end{tabular}

The common semes for the paradigm MAIN BODY are /part of tree/ and /location/, the latter of which has three values: /above ground/ vs. /outside the cambium/ /vs. /between vascular tissue and epidermis/.

Table 5.1 Common and variable semes of the English lexemes in the paradigm $M A I N$ BODY

\begin{tabular}{|l|l|l|}
\hline $\begin{array}{l}\text { Common semes: } \\
\text { /part of tree//location/ }\end{array}$ \\
\hline Variable semes: \\
\hline /location/ & \multicolumn{2}{|l|}{} \\
\hline /above ground/ & $\begin{array}{l}\text { /outside } \\
\text { cambium/ }\end{array}$ & $\begin{array}{l}\text { /between vascular } \\
\text { tissue and epidermis/ }\end{array}$ \\
\hline $\begin{array}{l}\text { TRUNK } \\
\text { STEM } \\
\text { BOLE }\end{array}$ & $\begin{array}{l}\text { BARK } \\
\text { RIND }\end{array}$ & \\
\hline
\end{tabular}

The opposition series in this paradigm is identified in terms of /location/, as illustrated in Table 5.1 above: /above ground/ vs. /outside the cambium/ vs. /between vascular tissue and epidermis/: TRUNK (based on the genus proximum 
STEM and the synonym BOLE), STEM (based on the genus proximum TRUNK), BOLE (based on the synonym TRUNK) vs. BARK, RIND (based on the genus proximum BARK) vs. CORTEX.

If the distinction between the lexemes BARK and CORTEX does not seem rigorous enough, the residual seme /texture/ with its two values /tough/ vs. /soft/ can be applied for a more clear-cut delineation between meanings. Thus, the following opposition series emerges: BARK, RIND vs. CORTEX.

The common semes for the paradigm CROWN are /part of tree/, /location (stem)/, and /age/ with the values /+mature $/{ }^{44}$ vs. /+young/, as illustrated in Table 5.2 below.

Table 5.2 Common and variable semes of the English lexemes in the paradigm CROWN

\begin{tabular}{|c|c|}
\hline \multirow{2}{*}{\multicolumn{2}{|c|}{$\begin{array}{l}\text { Common semes: } \\
\text { /part of tree/ /location (stem)/ /age/ } \\
\text { Variable semes: }\end{array}$}} \\
\hline & \\
\hline \multicolumn{2}{|c|}{ /age/ } \\
\hline /mature/ & /young/ \\
\hline $\begin{array}{l}\text { BRANCH } \\
\text { BOUGH }\end{array}$ & $\begin{array}{l}\text { SHOOT } \\
\text { SPROUT }\end{array}$ \\
\hline
\end{tabular}

The opposition series in this paradigm is established in terms of /age/: /mature/ vs. /young/: BRANCH, BOUGH vs. SHOOT, SPROUT. The full synonymy is confirmed in the case of the lexemes TRUNK=STEM=BOLE, BARK=RIND, BRANCH=BOUGH, SHOOT=SPROUT.

The parallel analysis of the Romanian and English lexicographic definitions reveals interesting observations. In the paradigm MAIN BODY, the configuration in the semic definitions changes, because the seme /function/ is absent in the English definitions. In the paradigm CROWN, the seme /shape/ disappears in the English definitions. There is a higher number of variable semes in Romanian, which would mean that the translation of the lexemes can only be approximated in English, because an exact equivalent does not exist. A case in point is the Romanian lexeme FUS, for which the multilingual dictionary does not provide an accurate English translation. In the same vein, it appears that the multilingual dictionary has misplaced CORTEX as an accurate equivalent for the lexemes SCOARŢĂ and COAJĂ.

If the synonymy is confirmed in the case of the lexemes TRUNCHI $=$ TULPINA $\breve{A}$ and TRUNK=STEM=BOLE, then the following

\footnotetext{
44 applied to the cases when the lexicographic definition does not explicitly state "young"
} 
equivalence is valid: TRUNCHI, TULPINA $=$ TRUNK, STEM, BOLE. Similarly, if the synonymy is confirmed in the case of the lexemes

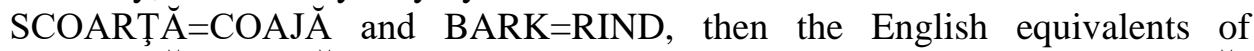
SCOART $\breve{A}$, COAJĂ are BARK, RIND. The Romanian lexemes RAMURĂ, CRACĂ, CREANGA and the English lexemes BRANCH, BOUGH are

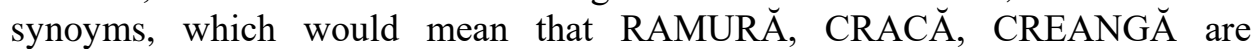
translated as BRANCH, BOUGH. Finally, if the synonymy is confirmed in the case of the lexemes LĂSTAR=LUJER=MLADA $\breve{A}$ and SHOOT=SPROUT, then LĂSTAR, MLADĂ, LUJER can be translated as SHOOT, SPROUT. There is a higher number of equivalents in English in the case of the lexemes TRUNCHI, TULPINĂ, the same amount in the case of SCOART $\breve{A}$, COAJÄ, and a lower number in the case of the lexemes RAMURĂ, CRACĂ, CREANGĂ, and LĂSTAR, LUJER, MLADĂ.

The English terminological definitions, extracted from the forestry glossary Terminology of forest science, technology practice and products (FordRobertson 1971) and listed in Table 6 below, are different from the lexicographic definitions in several ways. The terminological definition of the holonym TREE is "(botany) a woody perennial plant, typically large and with a single well-defined stem carrying a more or less definite crown", and the common semes are /woody plant/, /perennial/, /tall stem/, /crown/.

Table 6 The English lexemes and their terminological definitions

\begin{tabular}{|l|l|l|}
\hline PARADIGM & $\begin{array}{l}\text { ENGLISH } \\
\text { LEXEME }\end{array}$ & TERMINOLOGICAL DEFINITION \\
\hline \multirow{5}{*}{$\begin{array}{l}\text { MAIN } \\
\text { BODY }\end{array}$} & TRUNK & "bole” \\
\cline { 2 - 3 } & STEM & $\begin{array}{l}\text { "the principal axis of a plant, from which } \\
\text { buds and shoots develop" }\end{array}$ \\
\cline { 2 - 3 } & BOLE & $\begin{array}{l}\text { "a tree stem once it has grown to substantial } \\
\text { thickness - roughly, capable of yielding saw } \\
\text { timber, veneer logs or large poles, seedlings, } \\
\text { saplings and thinner poles" }\end{array}$ \\
\cline { 2 - 3 } & BARK & $\begin{array}{l}\text { "(wood structure) a non-technical term } \\
\text { covering all the tissues outside the xylem } \\
\text { cylinder" }\end{array}$ \\
\cline { 2 - 3 } & RIND & - \\
\cline { 2 - 3 } & CORTEX & $\begin{array}{l}\text { "(wood structure) the primary ground tissue } \\
\text { of a stem or root between the epidermis or } \\
\text { the phellem and the vascular system" }\end{array}$ \\
\hline \multirow{3}{*}{ CROWN } & BRANCH & - \\
\cline { 2 - 3 } & BOUGH & - \\
\cline { 2 - 3 } & SHOOT & "sprout; any young, slender, aerial outgrowth \\
\hline
\end{tabular}




\begin{tabular}{|l|l|l|}
\hline & $\begin{array}{l}\text { from a plant body, particularly a sprouting } \\
\text { stem or branchlet; often taken to include its } \\
\text { leaves” }\end{array}$ \\
\cline { 2 - 3 } & SPROUT & $\begin{array}{l}\text { (silviculture) generally, any shoot arising } \\
\text { from a (woody) plant” }\end{array}$ \\
\hline
\end{tabular}

Few of the terminological definitions include a field label: "wood structure", "silviculture". In the paradigm MAIN BODY, the seme /location/ can have three values, similarly to the lexicographic definitions. The variable semes are expressed in a slightly different manner in the case of the lexeme BARK, as underlined in the table below.

\begin{tabular}{|l|l|}
\hline Lexicographic definition & Terminological definition \\
\hline BARK & BARK \\
"the tough exterior covering of a woody & "(wood structure) a non-technical \\
root or stem; specifically the tissues & term covering all the tissues outside \\
outside the cambium that include an & the xylem cylinder" \\
$\begin{array}{l}\text { inner layer especially of secondary } \\
\text { phloem and an outer layer of periderm" }\end{array}$ & \\
\hline
\end{tabular}

In the paradigm CROWN, the common seme /shape/, which was absent in the lexicographic definitions, is added to the seme /age/ in the case of the terminological definitions of SHOOT and SPROUT (based on the genus proximum SHOOT), as underlined in the table below.

\begin{tabular}{|l|l|}
\hline Lexicographic definition & Terminological definition \\
\hline $\begin{array}{l}\text { SHOOT } \\
\text { "a stem or branch with its leaves and } \\
\text { appendages especially when not yet } \\
\text { mature" }\end{array}$ & $\begin{array}{l}\text { SHOOT } \\
\text { "sprout; any young, slender, aerial } \\
\text { outgrowth from a plant body, } \\
\text { particularly a sprouting stem or } \\
\text { branchlet; often taken to include its } \\
\text { leaves" }\end{array}$ \\
\hline $\begin{array}{l}\text { SPROUT } \\
\text { "shoot; especially a young shoot (as } \\
\text { from a seed or root)" }\end{array}$ & $\begin{array}{l}\text { SPROUT } \\
\text { "(silviculture) generally, any shoot } \\
\text { arising from a (woody) plant" }\end{array}$ \\
\hline
\end{tabular}

The lexemes RIND, BRANCH, and BOUGH are missing from the list, which indicates that they are not considered specialized. The full synonymy is confirmed in the case of the lexemes TRUNK=STEM=BOLE and SHOOT $=$ SPROUT.

There are relevant differences between the terminological definitions in Romanian and English. In the paradigm MAIN BODY, the common semes do 
not change, but the variable semes do. An example is the case of the lexemes SCOART $\breve{A}$ and COAJĂ, whose values within the common seme /location/ are expressed in a more general manner, i.e. /root, stem/ vs. /trunk, stem/. The terminological definitions of the lexemes BARK and CORTEX yield different variable semes, because location is expressed in a more particular manner: /outside the xylem cylinder/vs. /between the epidermis and the vascular system/. While the Romanian definitions focus on composition and function, abstracted in the form of residual semes, the English definitions rely on information about exact location, and this aspect requires further inquiry into other specialized sources for an exact identification of meaning. Thus, the Romanian - English equivalence between the lexemes SCOART $\breve{A}=$ COAJA $\breve{A}$ and BARK=CORTEX cannot be established based solely on their terminological definitions.

In the paradigm CROWN, the semes /shape/ and /age/, which are absent in the Romanian definitions, are present in the English definitions.

If the synonymy is confirmed in the case of the lexemes TRUNCHI=TULPINA $\breve{A}$ and TRUNK=STEM=BOLE, then the English equivalents of TRUNCHI, TULPINĂ are TRUNK, STEM, BOLE. The lexemes LĂSTAR=LUJER and SHOOT=SPROUT are also confirmed synonyms, so LĂSTAR, LUJER can be translated as SHOOT, SPROUT. The lexemes RAMURĂ, CRACĂ, SCOARŢĂ, and COAJĂ lack English equivalents. The number of equivalents in English is higher in the case of the lexemes TRUNCHI=TULPINĂ, and equal in the case of LĂSTAR=LUJER. Similarly to the analysis based on the lexicographic definitions, the Romanian lexemes FUS and MLADA seem to lack exact English translations in the multilingual dictionary, while the English lexeme CORTEX has been used as an English approximation for SCOART $\breve{A}$ and COAJĂ.

\section{CONCLUSIONS}

The aims of this synchronic, structural analysis were to identify terms denoting parts of a tree in Romanian and English, and to verify their equivalence in both languages. The first section of the paper describes the methodology used to achieve these aims, by giving various theoretical accounts on the lexical field theory and the field classification adopted herein. In the field typology proposed by Bidu-Vrănceanu and Forăscu (165), the lexical field of tree parts is polyparadigmatic, characterized by two paradigms which include the following non-comprehensive list of lexemes:

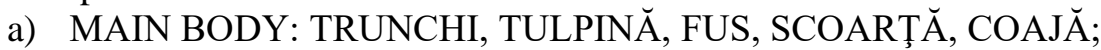

b) CROWN: RAMURĂ, CRACĂ, CREANGĂ, LĂSTAR, LUJER, MLADĂ.

After the formulation of the semic definitions of the Romanian lexemes, the lexicographic and terminological definitions were compared and contrasted 
in section two. The analysis showed that the semic definitions based on the lexicographic definitions seem more balanced, as seen in the opposition series of the variable semes. This aspect testifies to the descriptive nature of lexicographic definitions. The terminological definitions, on the other hand, rely more on encyclopedic information, based on the high number of residual semes which were necessary to contradict apparent synonymous pairs, e.g.

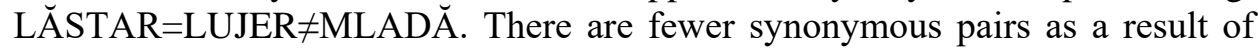
the terminological definitions in contrast to the lexicographic definitions, which is proof of the more rigorous nature of the former.

The third part of the article included the contrastive analysis of the English equivalents of the lexemes. The results revealed that the variable semes are similar in both types of definitions, with a small exception in the case of the terminological definitions of the lexemes in the paradigm CROWN, where the variable seme /shape/ is added to the configuration of the semic definitions of SHOOT and SPROUT. As far as the relation between the two language systems is concerned, there seems to be a one-to-one correspondence between the lexicographic sets of the two language systems (with the exception of FUS in Romanian and CORTEX in English), while the terminological set presents certain discrepancies. The pair RAMURA $=$ CRACA $\breve{A}$ and the lexemes FUS and MLADĂ do not find their English equivalents.

By setting out to identify terms denoting parts of a tree in Romanian and English, and to verify the equivalence between the two languages, a model for efficient lexical acquisition in L1 and / or in L2 emerged, through which inaccuracies in monolingual and bilingual lexicography can be detected and corrected, leading to a more effective method for learning and / or teaching L2 without sole reliance on a dictionary. The ultimate beneficiaries of this model of analysis are forestry students whose earlier, accurate acquisition of terminology in L1 and L2 can only contribute to their academic and professional success.

\section{Works Cited}

Bidu-Vrănceanu, Angela. Lexicul specializat în mişcare. De la dicţionare la texte. Bucureşti: Editura Universităţii din Bucureşti, 2007. Print.

---. Câmpuri lexicale din limba română: probleme teoretice şi aplicaţii practice. Bucureşti: Editura Universităţii din Bucureşti, 2008. Print.

Bidu-Vrănceanu, Angela and Narcisa Forăscu. Modele de structurare semantică. Cu aplicaţii la limba română (polisemie, sinonimie, antonimie, câmpuri). Timişoara: Editura Facla, 1984. Print.

Biriş, Gabriela. "Lexical and semantic fields in contemporary Romanian: pădure/forest denominations.” Studii şi cercetări de onomastică şi lexicologie IV.1-2. Craiova: Editura Sitech, 2011. 144-53. Print. 
Botnaru, Ana-Maria. “A few remarks on the forest terminology in Romanian”. Studii şi cercetări de onomastică şi lexicologie. I.1-2. Craiova: Editura Sitech, 2008. 3542. Print.

Bowker, Lynne. "Specialized Lexicography and Specialized Dictionaries”. A Practical Guide to Lexicography. Ed. Piet van Sterkenburg. Amsterdam: John Benjamins, 2003. 154-64. Print.

Burada, Marinela and Raluca Sinu. Research and Practice in Lexicography. Braşov: Editura Universităţii Transilvania din Braşov, 2016. Print.

Coşeriu, Eugenio. "Vers une typologie des champs lexicaux”. Cahiers de lexicologie, XXVII, 1975. 30-51. Print.

Cruse, Alan Meaning in Language. An Introduction to Semantics and Pragmatics, New York: Oxford University Press, 2000. Print.

Geeraerts, Dirk. Theories of Lexical Semantics, New York: Oxford University Press, 2010. Print.

Lipka, Leonhard. "Methodology and representation in the study of lexical fields". Perspektiven der lexikalischen Semantik, 1977. 93-114. Print.

Lyons, John. Semantics. London: Cambridge University Press, 1977. Print.

Riemer, Nick. Introducing Semantics. Cambridge: Cambridge University Press, 2010. Print.

\section{Dictionaries}

Bidu-Vrănceanu, Angela, Cristina Călăraşu, Liliana Ionescu-Ruxăndoiu, Mihaela Mancaş, Gabriela Pană-Dindelegan. Dicţionar de Ştiinţe ale Limbii. Bucureşti: Nemira. 2001. Print.

Dicţionarul explicativ al limbii române. Bucureşti: Editura Univers Enciclopedic. 2009. Print.

Dincă, Lucian, Dorin Drăghiciu, Dănuţ Chira. Dicţionar forestier poliglot român-englezfrancez-german. Bucureşti: Editura Silvică. 2011. Print.

Ford-Robertson, F.C., ed. Terminology of forest science, technology practice and products. Washington D.C.: Society of American Foresters. 1971. Print.

Merriam-Webster online dictionary. Web. https://www.merriam-webster.com/

Popovici, Traian. Terminologia forestieră română. Braşov: Editura Universităţii din Braşov. 1978. Print. 